\title{
OBESITY-RELATED SELF-ESTEEM AND ITS RELATIONSHIP TO COPING WITH STRESS
}

\author{
Andrzej NIEŚPIAŁOWSKI', Jan F. TERELAK² \\ ${ }^{1}$ Cardinal Stefan Wyszynski University in Warsaw, Institute of Psychology, Warsaw, Poland \\ ${ }^{2}$ Military Institute of Aviation Medicine in Warsaw, Warsaw, Poland
}

Source of support: Own sources

Author's address: A. Nieśpiałowski, Cardinal Stefan Wyszynski University in Warsaw, Institute of Psychology, Dewajtis 5 Street, 00-001 Warsaw, Poland, e-mail: niespiall14@gmail.com

Introduction: The aim of this work was to determine the relationship between self-esteem and styles of coping with stress in obese people.

Methods: We included 62 adults with both obesity and with normal weight (men and women). Participants were qualified to either group based on their Body Mass Index values. We performed the assessments with the use of Rosenberg Self-esteem Scale (SES) and Coping Inventory for Stressful Situations (CISS) by Endler and Parker.

Results: Based on our statistical analyses, the assumption that obese people had a lower level of self-esteem in comparison to people with normal weight was confirmed. Moreover, the most commonly used coping style in people with obesity was emotion-oriented. Based on further statistical analysis, low self-esteem was a significant predictor of both the emotion-oriented and the avoidance-oriented coping style in the form of distraction (DIS).

Discussion: Regulation and protection of cognitive resources from the influence of obesity-related stress is reflected by the concentration on negative emotions and external compensatory behaviors aimed at mentally escaping from the non-acceptable body image.

Conclusions: It was found that obese people are characterized by a lower level of self-esteem than people with normal weight. Moreover, obese people prefer emotion-oriented and avoidance-oriented coping styles and rarely use task-oriented coping.

Keywords: obesity, self-esteem, coping stress

Tables: 8 - References: 29 - Full-text PDF: http://www.pjambp.com • Copyright (C) 2016 Polish Aviation Medicine Society, ul. Krasińskiego 54/56, 01-755 Warsaw, license WIML • Indexation: Index Copernicus, Polish Ministry of Science and Higher Education 


\section{INTRODUCTION}

Obesity is a problem that has been increasingly spreading around the world. According to a report of the World Health Organization (WHO) from February 2010, approximately one billion adults are overweight and over 300 million are obese. Along with an increase in obesity rates in children, adolescents and adults, several negative ramifications have been seen in the following areas: health (i.e. type 2 diabetes, disorders of the respiratory, gastrointestinal and musculoskeletal systems), social area (i.e. social discrimination) and psychological area (i.e. increased levels of experienced stress, anxiety, lower self-esteem, lower level of self-efficacy, etc.)[11-13,21,28].

Numerous authors (e.g. Juruć and Bogdański, 2010; Kirenko and Wiatrowska, 2015, chapter 1; Makara-Studzińska et al., 2007; Ogińska-Bulik, 2004, chapter 2,3) emphasize that obese people have decreased self-esteem and in stressful situations prefer coping strategies oriented on defence/avoidance $[6,12,19]$. It is accepted that self-esteem, being one of the most important regulators of human behavior, is shaped throughout the entire life of an individual $[7,15]$. Some authors put forward that self-esteem, whether high of low, depends on individual traits as well as on the surrounding external environment, including other people [23]. It should be underlined that obese people, owing to their increased weight, are an object of negative opinions and convictions relating primarily to the external appearance. It should be stressed that such convictions lead to the formation of stereotypes and prejudices that relate to an entire person including personal characteristics [11], which can, in turn, influence the level of self-esteem of obese individuals who might subsequently tend to avoid interaction with the external world and society [25].

Numerous authors determined that people with low self-esteem, when compared to people with optimal or high self-esteem, tend to cope poorly with emotions and difficult situations that can be caused by high levels of stress. Moreover, such people tend to avoid stress rather than engage in actions aimed at overcoming it $[7,25]$.

The aim of this work was to determine if and to what extend the level of self-esteem can influence the use of preferred styles of coping with stress in people with obesity. The theoretical context includes the theory of self-esteem by Morris Rosenberg and styles of coping with stress.

\section{Theory of self-esteem by Morris Rosenberg}

Currently, self-esteem is one of the most widely studied concepts in social psychology. Usually, it is accepted as one of the "most important regulators of behavior; actions aimed at elevating selfesteem are viewed as one of the most basic motivations of the individual" $[5,14,15]$.

According to Rosenberg, self-esteem denotes either a "positive" or a "negative" attitude towards the very special object, i.e. the Self [23, s. 30]. According to Rosenberg, the most important role of self-esteem is to motivate the individual. Self-esteem reinforces or protects a positive image of the Self throughout life and is regulated by a number of dynamic social interactions that are based on two social mechanisms, known in the psychological literature as appraisals and social comparisons. Depending on whether these two mechanisms are positive or negative, they either reinforce (positive appraisals of other people/positive social comparisons) or lower (negative appraisals of other people/negative social comparisons) the level of the general well-being/self-esteem [24].

The level of self-esteem is one of the basic causes that contribute to the differences in cognition and behavior between people with high and low self-esteem. High self-esteem is characterized by Rosenberg [23 p. 31] as the feeling of being "sufficiently good", "valuable", "self-respecting" and "self-confident". According to Rosenberg, low selfesteem leads to self-rejection, self-dissatisfaction and self-contempt. Thus, people with low selfesteem do not accept themselves, are dissatisfied with themselves and show lack of respect towards themselves. Moreover, people with low self-esteem very often tend to be too susceptible to criticism and symptoms of rejection and maladjustment to the surrounding world. Consequently, this leads to protective coping with stress and being passive towards people and situations that can endanger self-image [25].

\section{Theory of styles of coping with stress by N.S. Endler and J.D.A. Parker}

The theory of styles of coping with stress by Endler and Parker relates to the interactive model of stress by Lazarus and Folkman $[8,17,18]$. In any particular stressful situation, behavior is the result of interaction between the situation and the style of coping - seen as a relatively stable disposition towards selecting particular coping strategies under stressful conditions [9] and aimed at problem - focused coping or emotion - focused coping [17]. Based on this, Endler and Parker [8] differentiated the following coping styles: task-oriented coping, emotion-oriented coping and avoidance-oriented coping. Task-oriented coping determines the 
likelihood that the individual will try to overcome a stressful situation by cognitive re-appraisal or by changing the situation itself. Emotion-oriented coping characterizes people who tend to concentrate on their own emotions experienced under stressful conditions. Avoidance-oriented coping determines the likelihood that the individual will tend not to think of stress in order not to experience it. This style can be found in two forms; namely, distraction (e.g. watching television, overeating, actions that are aimed at avoiding stress, etc.) and social diversion (e.g. seeking support in a stressful situation by talking to a friend, colleague or a loved-one, etc.).

\section{Characteristics of obesity-related stress}

Currently, increasing rates of obesity have been noticed, especially in children and adolescents [10]. This disease is one of the most quickly developing epidemics of the 21st century and it begins to pose a serious global problem [11]. According to the World Health Organization, obesity is "a chronic disease that is not self-limiting and is characterized by a constellation of symptoms related to (1) external factors such as stress, improper nutrition or lack of physical activity and to (2) internal factors such as genetics, metabolism and degenerative processes [21 p. 42]. In the common view, obesity is characterized by increased body weight and by excessive adipose tissue. Obesity is diagnosed when body weight has increased to over $20 \%$ of the normal weight. Obesity leads to negative health consequences (i.e. type 2 diabetes, disorders of respiratory, gastrointestinal and musculoskeletal systems, increased risk of certain cancers, cardiovascular diseases - predominantly ischemic heart disease and arterial hypertension) and psychosocial consequences [13].

Among the most common social consequences of obesity one has to name discrimination, as obese people are often perceived as less attractive or having negative personal characteristics such as lack of self-discipline, self-control, laziness, messiness or hostility towards others [28]. Some authors [21] think that such stereotypes often contribute to the fact that obese people, when compared to people with normal weight, have problems with achieving success in both private and professional life, i.e. finding proper jobs, renting a house, finding a partner, etc.

As regards the psychological consequences, obese people tend to experience more anxiety and stress. They also have lower self-esteem, lower selfefficacy and experience many negative emotions that can lead directly or indirectly to various psychological disorders [12,19,21].

\section{Obesity and self-esteem}

Many authors emphasize that obesity is associated with lower self-esteem at an individual level $[11,12]$. Other authors underline that this phenomenon is most pronounced among obese children and adolescents $[21,21,22]$ in whom obesity negatively influences primarily the body image $[3,4]$. Juruć and Bogdański [11] suggest that in some people such a negative body image can spread to other aspects of life, leading to over-generalization and hopelessness in various domains of life (e.g. work, emotional life). They also emphasize that low self-esteem does not necessarily result solely from obesity but also, in an indirect way, from its social consequences such as negative social judgments, lack of support or unjust social stereotypes relating to obesity.

\section{Obesity and styles of coping with stress}

In the literature on the subject matter, chronic stress and elevated cortisol levels associated with it are risk factors of abdominal obesity [1]. Various authors also indicate that obese people are more commonly characterized by low self-esteem, prefer emotion-oriented coping strategies as opposed to strategies that could be oriented on confronting obesity-related stress $[2,6,11]$. These ineffective strategies of coping with obesity are characterized by avoidance and compensatory behaviors (e.g. overeating under stressful conditions) or concentration on negative emotions, which leads to further weight gain [12]. Some authors point out that people with the so-called simple obesity often have feelings of helplessness and lack of influence, which is associated with a tendency to use passive/ defensive coping strategies $[8,11,25]$. Brytek-Matera [3] found that obese people are more likely than people with normal weight to use emotion - and avoidance-oriented strategies that lead to high levels of discontent with external appearance, especially in obese women, and to a lower motivation to fight with stress. Rydén et al. [26] found that people who were planned for surgical treatment of obesity had lower scores in task-oriented coping and higher scores in emotion-oriented coping. They also noted that emotion-oriented coping was associated with increased depression and despair, while task-oriented strategies were more adaptive, contributing to a reduction in negative emotions.

\section{Subject of our research}

The main aim of this research was to assess the influence of self-esteem on the preferential use of strategies of coping with stress in obese people. 
Taking into account the theoretical basis described above, we put forward the following hypotheses:

$\mathrm{H} 1$ : In obese people, low self-esteem is associated with a preferential use of coping strategies oriented on emotions.

H2: In obese people, low self-esteem is associated with avoidance-oriented coping in the form of distraction ( $\mathrm{H} 2.1)$ and social diversion $(\mathrm{H} 2.2$.$) .$

H3: Obese people have lower scores on self-esteem scales than people with normal weight.

$\mathrm{H} 4$ : Obese people have significantly lower scores on the scales measuring emotion-oriented coping in comparison to people with normal weight who prefer task-oriented coping with stress.

H5: Obese people have significantly higher scores on the scales measuring avoidance-oriented coping in comparison to people with normal weight both in the form of distraction (H5.1) and social diversion (H5.2.).

\section{METHODS}

\section{Characteristics of studied groups}

We included 62 adults with obesity and normal weight who were classified into two groups based on the Body Mass Index (BMI). According to WHO, obesity in adults is diagnosed when this index is equal to or greater than 30 , and overweight is diagnosed when it is equal to or greater than 25 . The distribution of the BMI in the studied groups (experimental and control) is shown in Tables 1 and 2.

The experimental group consisted of 31 obese adults, while the control group consisted of 31 participants with normal weight. The two groups had equal numbers of participants as well as equal male-to-female ratios. In either group, the age range was 23-54 years (21 women and 10 men).

Based on the data presented in Table 1, BMI was higher than 40 in 11 participants from the experimental group ( 9 women and 2 men; $35.48 \%$ in total sample), which is a testimony to a high degree of obesity. BMI of the remaining participants from this group was 30-39.99; and the greatest proportion (41.9\%) was comprised by people with degree I obesity.

Based on data in Table 2, all participants in the control group had BMI values between 18.5 and 24.99, which indicates normal weight.

\section{Following tools}

In order to verify our hypotheses, we applied the two following tools:

- Rosenberg Self-esteem Scale (SES), in the Polish adaptation by I. Dzwonkowska, K. Lacho-

Tab. 1. BMI in the experimental group.

\begin{tabular}{|c|c|c|c|}
\hline Categories & Men & Women & Total \\
\hline$>40 * * *$ & 2 & 9 & 11 \\
\hline$\%$ within given group & 20 & 42.9 & \\
\hline$\%$ in total sample & 6.5 & 29 & 35.5 \\
\hline $35-39.99 * *$ & 3 & 4 & 7 \\
\hline$\%$ within given group & 30 & 19 & \\
\hline$\%$ in total sample & 9.7 & 12.9 & 22.6 \\
\hline $30-34.99 *$ & 5 & 8 & 13 \\
\hline$\%$ within given group & 50 & 38.1 & \\
\hline$\%$ in total sample & 16.1 & 25.8 & 41.9 \\
\hline In sum & 10 & 21 & 31 \\
\hline Total & $32.3 \%$ & $67.7 \%$ & $100 \%$ \\
\hline
\end{tabular}

*** III degree of obesity: morbid obesity

** II degree of obesity (clinical obesity)

* I degree of obesity

Tab. 2. BMI in the control group.

\begin{tabular}{|c|c|c|c|}
\hline Categories & Men & Women & Total \\
\hline 18.5-24.99* & 10 & 21 & 31 \\
\hline$\%$ within given group & 100 & 100 & \\
\hline$\%$ in total sample & 32.3 & 67.7 & 100 \\
\hline In sum & 10 & 21 & 31 \\
\hline Total & 32.3 & 67.7 & 100 \\
\hline
\end{tabular}

* Normal weight 
wicz-Tabaczek and M. Łaguna [7]. SES measures global self-esteem referring to a global wellbeing. The level of self-esteem is disclosed in self-report measures and is considered to be a stable trait. Morris Rosenberg differentiated two poles of self-esteem [24]: low self-esteem and high self-esteem. SES includes 10 items referring to a general well-being on a four-degree scale with no intermediate response. Possible answers include: 1 - strongly agree, 2 - agree, 3 - disagree, 4 - strongly disagree. Therefore, the maximal score is 40 points with higher scores indicating higher self-esteem,

- Coping Inventory for Stressful Situations (CISS) by N.S. Endler and J.D.A. Parker in the Polish adaptation by J. Strelau et al. [27]. CISS consists of 48 items referring to various behaviors undertaken in stressful situations. Each item is responded to on a five-degree scale. Possible answers include: 1 - never, 2 - very rarely, 3 - sometimes, 4 - often, 5 - very often. The questionnaire consists of 3 subscales, i.e. Task-Oriented Coping (TOC), Emotion-Oriented Coping (EOC) and Avoidance-Oriented Coping (EOC). On each of these subscales, a score between 16 and 80 points can be obtained with higher scores indicating a higher likelihood of using a given style of coping. Each subscale can be characterized in the following way:

- Task-Oriented Coping (TOC) determines the frequency with which a person undertakes specific efforts aimed at resolving stressful situations; this may include cognitive re-appraisal or changing the situation itself,

- Emotion-Oriented Coping (EOC) is characterized by a tendency to concentrate on emotions under stressful conditions. People with high scores on this scale tend to be characterized by wishful thinking and fantasizing. Such actions are aimed at reducing emotional tension created by a particular stressful situation. However, this can sometimes be unsuccessful and lead to a paradoxical increase of emotional tension and stress,

- Avoidance-Oriented Coping (AOC) determines the frequency with which people tend to avoid thinking, perceiving and experiencing stressful situations. Avoidance-oriented coping comes in two forms - (1) Distraction (DIS) - e.g. watching television, overeating, "giving oneself some rest" in order to avoid the problem; and (2) Social diversion (SDV) - e.g. seeking social support.

\section{Experimental procedure}

In February 2016, the experimental group was recruited in one of the obesity clinics in Warsaw, Poland. The group was recruited randomly, based on a single criterion of $\mathrm{BMI}$ equal to or greater than 30. All participants expressed an informed consent. Participants completed, in a random order, the following scales - Rosenberg Self-esteem Scale (SES) and Coping Inventory for Stressful Situations (CISS).

Similarly, based on BMI, age and gender, a control group was also recruited.

\section{RESULTS}

\section{Influence of self-esteem on the use of coping styles in obese people}

In order to verify the degree to which selfesteem predicts the use of styles of coping with stress in obese people, we used linear regression. The data showing how self-esteem predicts the use of emotion-oriented and avoidance-oriented coping by obese people are presented in Table 3.

Tab. 3. Influence of self-esteem (SES) on the use of emotion-oriented coping in obese people.

\begin{tabular}{lcccc}
\hline & $\mathbf{R}^{\mathbf{2}}$ & $\mathbf{F}$ & B coefficient & Coefficient $\boldsymbol{\beta}$ \\
\hline EOC & 268 & 10.63 & -1.078 & $-.518^{* *}$ \\
\hline AOC & .042 & 1.27 & -.315 & -.205 \\
\hline DIS & .263 & 10.37 & -.525 & $-.513^{* *}$ \\
\hline SDV & .070 & 2.19 & .224 & .265
\end{tabular}

Legend: ${ }^{*} \mathrm{p}<0.05 ;{ }^{* *} \mathrm{p}<0.01$; Self-esteem Scale -SES; task-oriented coping - TOC $;$ emotion-oriented coping - EOC avoidance-oriented coping-AOC; distraction - DIS; social diversion - SDV.

Self-esteem significantly predicts the use of emotion-oriented coping (EOC) and explains $27 \%$ of this variable's variance. With an increase in selfesteem of 1 point, the mean score of emotion-oriented coping decreased by 1.08 points; therefore, hypothesis 1 was confirmed. As regards avoidance-oriented coping (AOC), self-esteem was not a significant predictor. However, distraction (DIS) significantly predicts $26 \%$ of the variance of selfesteem. With an increase in self-esteem of 1 point, the distraction score decreases by 0.53 points; therefore, the hypothesis was confirmed. Self-esteem was not a significant predictor of avoidanceoriented coping in the form of social diversion.

Differences in the level of self-esteem between obese people and people with normal weight.

Before performing the analysis, the distributions of all variables were checked. The distribution of self-esteem scores, AOC and its form - DIS, were not different from the normal distribution, 
whereas the distributions of the remaining variables - TOC, EOC and SDV were not normal.

The groups of obese people and people with normal weight were compared with the use of appropriate statistical tests; the Student t-test was used for normally distributed data (SES, AOC, DIS), whereas the Mann-Whitney test was used for non-normally distributed data (TOC, EOC, SDV). The results of the parametric significance test for differences in general self-esteem between obese people and people with normal weight are presented in Table 4.

Tab. 4. Comparison of mean self-esteem scores (SES) between obese people and people with normal weight with the use of the t-Student test.

\begin{tabular}{ccccccc}
\hline & \multicolumn{2}{c}{ Obese people } & \multicolumn{5}{c}{ People with normal weight } \\
\cline { 2 - 7 } & M & SD & M & SD & $d f$ & $t$ \\
\hline SES & 27.61 & 5.77 & 33.55 & 2.86 & 60 & $5.13^{* *}$ \\
\hline
\end{tabular}

$* * p<0.01$

People with normal weight had significantly higher scores in self-esteem (SES) than obese people.

The results of the nonparametric significance test for differences in task-oriented coping between obese people and people with normal weight are presented in Table 5.

Tab. 5. Comparison of mean task-oriented coping scores (TOC) between obese people and people with normal weight with the use the U Manna-Whitney test.

\begin{tabular}{cccccc}
\hline & \multicolumn{2}{c}{ Obese people } & \multicolumn{3}{c}{ People with normal weight } \\
\cline { 2 - 6 } & Mean ran & Sum of ranks & Mean rank & Sum of ranks & $U$ \\
\hline TOC & 20.60 & 638.50 & 42.40 & 1314.50 & $142.50^{* *}$ \\
\hline
\end{tabular}

$* * p<0.01$

People with normal weight had significantly higher scores in task-oriented coping (TOC) in comparison to obese people.

The results of the nonparametric significance test (Mann-Whitney test) for differences in emotion-oriented coping between obese people and people with normal weight are presented in Table 6.

Tab. 6. Comparison of mean emotion-oriented coping scores (EOC) between obese people and people with normal weight with the use the U Manna-Whitney test.

\begin{tabular}{cccccc}
\hline & \multicolumn{2}{c}{ Obese people } & \multicolumn{3}{c}{ People with normal weight } \\
\cline { 2 - 6 } & Mean ran & Sum of ranks & Mean rank & Sum of ranks & $U$ \\
\hline EOC & 37.52 & 1163.00 & 25.48 & 790.00 & $294.00^{*}$ \\
\hline
\end{tabular}

* $p<0.05$

Obese people had significantly higher scores in emotion-oriented coping (EOC) in comparison to people with normal weight.
The results of the t-Student test for differences in avoidance-oriented coping (AOC) and its subscale - distraction (DIS), between obese people and people with normal weight are presented Table 7.

Tab. 7. Comparison of differences in avoidanceoriented coping (AOC) and its subscale distraction (DIS), between obese people and people with normal weight with the use to the t-Student test.

\begin{tabular}{ccccccc}
\hline & \multicolumn{3}{c}{ Obese people } & \multicolumn{5}{c}{ People with normal weight } \\
\cline { 2 - 7 } & M & SD & M & SD & $d f$ & $t$ \\
\hline AOC & 41.68 & 8.86 & 43.97 & 7.86 & 60 & 1.08 \\
\hline DIC & 19.58 & 5.90 & 18.35 & 4.83 & 60 & -0.89 \\
\hline
\end{tabular}

There were no significant differences between obese people and people with normal weight in avoidance-oriented coping and in its subscale distraction (DIS).

The results of the nonparametric significance test (Mann-Whitney test) for differences in avoidance-oriented coping in the form of social diversion (SDV) between obese people and people with normal weight are presented in Table 8.

Tab. 8. Comparison of mean scores in avoidanceoriented coping in the form of social diversion (SDV) between obese people and people with normal weight with the use the $U$ MannaWhitney test.

\begin{tabular}{lccccc}
\hline & \multicolumn{2}{c}{ Obese people } & \multicolumn{3}{c}{ People with normal weight } \\
\cline { 2 - 6 } & Mean ran & Sum of ranks & Mean rank & Sum of ranks & $U$ \\
\hline EOC & 37.52 & 1163.00 & 25.48 & 790.00 & $294.00^{*}$ \\
\hline$* p<0.05$ & & & & & \\
\end{tabular}

People with normal weight had significantly higher scores in social diversion than obese people.

\section{DISCUSSION}

Linear regression analysis confirmed the majority of hypotheses that were put forward in this study. Low self-esteem in obese people was a significant predictor of emotion-oriented coping, which is in line with the understanding of emotional coping proposed by Lazarus and Folkman [18] in which this kind of coping is employed to protect mental resources from the negative effects of stress. Our results are also in line with studies performed by other authors who studied obesity-related stress and regard obesity as one of the most serious civilization disease of the 21st century, especially in the countries with high consumption $[11,12,21]$. Difficulties in daily functioning, social exclusion, disturbed self-image with resultant low self-esteem and many other negative ramifications of obesity all contribute to experiencing negative emotions by obese people who cannot always successfully cope with them. 
We partially confirmed the second hypothesis on the preferential use of avoidance-oriented coping strategies by obese people who engaged in distraction.

Obesity, as pointed out by some authors, is associated with a limited ability of obese people to adapt to different conditions and requirements of the environment. [12]. These difficulties result directly from obesity itself but also from its negative ramifications such as lack of support and understanding [11], which results in poor interpersonal relations. Negative discriminatory attitudes and obesity-related stereotypes can contribute to low self-esteem in obese people and consequently lead to social isolation and worse social functioning as reflected by passive coping strategies with stress such as engaging in distractive actions, among which overeating is most commonly reported [12]. Eating is easily available and produces positive emotions that balance the negative obesity-related stress; moreover, it distracts attention from negative stimuli and activates the reward system in the brain $[21,29]$.

The main aim of this study was to find out if there were differences in self-esteem and in the use of particular coping strategies between obese people and people with normal weight. In the literature on the subject matter, there is evidence pointing towards such differences $[2,3,6]$, and this study also confirmed them. Our statistical analysis, based on significance tests, showed that there were differences between obese people and people with normal weight in self-esteem, taskoriented coping, emotion-oriented coping and avoidance-oriented coping in the form of social diversion.

Obese people had a significantly lower level of self-esteem than people with normal weight, which is in line with previous studies suggesting that obesity predisposes to lower self-esteem both directly through negative health outcomes and indirectly through social isolation of obese people in contemporary societies $[11,12,21]$. Based on the relevant theoretical assumptions, it seems that low self-esteem in obese people could be partially determined by two social mechanisms shaping self-esteem that were put forward by Rosenberg, i.e. negative social comparisons and negative social appraisals $[24,25]$. The influence of these processes on self-esteem in obese people, especially in the developed countries, can result from social stigmatization, discrimination and rejection seen in cultures that praise slim appearance [21].

As regards task-oriented coping, it was confirmed that obese people use this coping strategy significantly less commonly than people with normal weight. This is in line with the theory of Endler and Parker who point out that this strategy is the most adaptive way of coping with stress. One might suggest that the preferential use of taskoriented coping by people with normal weight in comparison to obese individuals can stem from unequal social opportunities, since obese people have negative experiences on a daily basis and this worsens their well-being and social functioning $[11,21]$.

As regard emotion-oriented coping, obese people used this kind of coping more commonly than people with normal weight, which is in line with previous research $[3,26,29]$. According to Lazarus and Folkman [16], emotion-oriented coping protects the individual from negative consequences of stress but does not directly resolves the stress transaction itself. Such people try to achieve emotional balance in a given stressful situation but do not try to resolve is directly [27].

As regards avoidance-oriented coping in the form of social diversion, obese people used this strategy significantly less commonly than people with normal weight. This confirms our assumptions and can indicate that obese people do not seek social support from friends or family when coping with obesity itself and its negative ramifications (e.g. negative social attitudes towards obesity, hurting stereotypes). This is associated with decreased self-esteem in obese people (illustrated in Table 8), which is in line with Rosenberg's conception that low self-esteem does not help in social functioning in a given social environment [25].

An interesting finding is that there were no statistically significant differences in avoidanceoriented coping between obese people and people with normal weight. This might stem from the fact that adult individuals are convinced, based on life experiences, that escaping from stress is not a rational solution even as a temporary emotional relief.

\section{CONCLUSIONS:}

1. We found that obesity can significantly reduce self-esteem in obese people and by that can lead to poor social and mental functioning as well as social isolation.

2. W confirmed that obese people preferentially use emotion-oriented coping, which is reflected by the use of mental strategies that are characterized by an excessive concentration on internal emotional states or compensatory behaviors. 
3. We found that obese people preferentially used avoidance-oriented coping in the form of distraction with overeating being one of the most important behaviors.

4. We found differences between obese people and people with normal weight in:

- self-esteem - self-esteem in obese people is lower than in the control group,
- styles of coping with stress - people with normal weight preferentially use taskoriented coping, whereas obese people preferentially use emotion-oriented coping.

5. We did not find differences between the studied groups in avoidance-oriented coping.

\section{AUTHORS' DECLARATION:}

Study Design: Andrzej Nieśpiałowski, Jan F. Terelak; Data Collection: Andrzej Nieśpiałowski; Manuscript Preparation: Jan F. Terelak; Funds Collection: Andrzej Nieśpiałowski, Jan F. Terelak. The Authors declare that there is no conflict of interest.

\section{REFERENCES}

1. Barrington WE, Ceballos RM, Bishop SK, McGregor BA, Beresford SA A. Perceived Stress, Behavior, and Body Mass Index Among Adults Participants in a Worksite Obesity Prevention Program, Seattle, 2005-2007. Preventing Chronic Disease, 2012, (9), dostępny [on-line]: 08.04.2016.

2. Bąk-Sosnowska M, Naworska B, Owczarek A, Chudek J, Skrzypulec-Plinta V, Olszanecka-Glinianowicz M. Strategie radzenia sobie z nadmierną masą ciała oraz szacunek do siebie i własnego ciała w kontekście analizy transakcyjnej. Psychiatria Polska 2014; 48(3): 477-487.

3. Brytek-Matera A. Obraz własnego ciała u otyłych kobiet: przyczyny i stopień niezadowolenia, związek z obniżoną samooceną i strategiami radzenia sobie ze stresem. Psychiatria Polska 2010; 44(2): 267-275.

4. Buczak A, Samujło M. Samoocena globalna i postrzeganie własnego ciała a zachowania żywieniowe studentów. Lubelski Rocznik Pedagogiczny 2013; 32: 232-242.

5. Cast AD, Burke PJ. A Theory of Self-Esteem. Social Fources 2002; 80(3): 1041-1068.

6. Chanduszko-Salska J, Chodkiewicz J. Zadowolenie z życia a poczucie własnej skuteczności, wsparcie społeczne oraz stan zdrowia u kobiet z nadwagą i otyłością. Endokrynologia. Otyłość i Zaburzenia Przemiany Materii 2010; 6(4): 171-178.

7. Dzwonkowska I, Lachowicz-Tabaczek K, Łaguna M. Samoocena i jej pomiar. Polska adaptacja skali SES M. Rosenberga (rdz.1) Warszawa: Pracownia Testów Psychologicznych Polskiego Towarzystwa Psychologicznego 2008.

8. Endler NS, Parker JDA. Assessment of multidimensional coping: task, emotion, and avoidance strategies. Psychological Assessment 1994; 6(1): 50-60.

9. Heszen-Niejodek I. Stres i radzenie sobie: główne kontrowersje. W: Heszen-Niejodek I, Ratajczak Z. (red.): Człowiek w sytuacji stresu: Problemy teoretyczne i metodologiczne. Katowice: Wydawnictwo Uniwersytetu Śląskiego 2000: 12-43.

10. Izdebski P, Rucińska-Niesyn A. Psychologiczne uwarunkowania otyłości u dzieci - rola rodziny. Rocznik Naukowy Nauki o Edukacji Kujawsko-Pomorskiej Szkoły Wyższej w Bydgoszczy 2009; 4: 149-159.

11. Juruć A, Bogdański P. Otyłość i co dalej: O psychologicznych konsekwencjach nadmiernej masy ciała. Forum Zaburzeń Metabolicznych 2010; 1(4): 210-219.

12. Kirenko J, Wiatrowska A. Otyłość: przystosowanie i uwarunkowania (rdz.1-3, 5). Lublin: Wydawnictwo Uniwersytetu Marii Curie-Skłodowskiej 2015.

13. Kłosiewicz-Latoszek L. Otyłość jako problem społeczny, zdrowotny i leczniczy. Problemy Higieny i Epidemiologii 2010; 91(3): 339-343.

14. Kohler-Flynn H. Self-esteem theory and Measurement: A critical Review. Thirdspace: A journal of feminist theory and culture 2003; 3(1), dostępny [on-line]: 20.01.2016. 
15. Lachowicz-Tabaczek K, Śniecińska J. Samowiedza i samoocena: wzajemne relacje. W: A. Niedźwieńska, J. Neckar (red.): Poznaj samego siebie czyli o źródłach samowiedzy. Warszawa: Wydawnictwo Szkoły Wyższej Psychologii Społecznej Academica, 2009: 238-270.

16. Lazarus R. S, Folkman S. Stress, appraisal and coping (rdz.1-10). New York: Springer Publishing Company 1984.

17. Lazarus RS. Paradygmat stresu i radzenia sobie. Nowiny Psychologiczne 1986: 3-4, 2-39.

18. Lazarus RS. Coping theory and research: past, present and future. Psychosomatic medicine 1993; 55(3): $234-247$.

19. Makara-Studzińska M, Buczyjan AM, Morylowska J. Jedzenie - przyjaciel i wróg. Korelaty psychologiczne otyłości. Przegląd piśmiennictwa, Zdrowie Publiczne 2007; 117(3): 392-396.

20. Makara-Studzińska M, Zaborska A. Otyłość a obraz własnego ciała. Psychiatria Polska 2009; 33(1): $109-114$.

21. Ogińska-Bulik N. Psychologia nadmiernego jedzenia: przyczyny, konsekwencje, sposoby zmiany (rdz.2-3). Łódź: Uniwersytet Łódzki 2004.

22. Radoszewska J. Psychiczne i społeczne konsekwencje otyłości. W: Oblacińska A, Woynarowska B. (red): Otyłość. Jak leczyć i wspierać dzieci i młodzież. Warszawa. Instytut Matki i Dziecka 1995: 33-34.

23. Rosenberg M. Society and the Adolescent Self-Image (rdz.1-5). New Jersey. Princeton University Press 1965.

24. Rosenberg M. Conceiving the Self (rdz.1-6, 11). New York: Basic Books 1979.

25. Rosenberg M, Owens TJ, Low Self-Esteem People: A Collective Portrait. W: Owens TJ, Stryker S, Goodman N. (red.): Extending Self-Esteem Theory and Research: Sociological and Psychological Currents. New York: Cambridge University Press 2006: 400-436.

26. Rydén A, Karlsson J, Persson LO, Sjöström L, Taft C, Sullivan M. Obesity-related coping and distress and relationship to treatment preference. British Journal of Clinical Psychology 2001; 40(2): 177-188.

27. Strelau J, Jaworowska A, Wrześniewski K, Szczepaniak P. Kwestionariusz Radzenia Sobie w Sytuacjach Stresowych - CISS. Podręcznik do polskiej normalizacji (rdz.1-6).Warszawa: Pracownia Testów Psychologicznych Polskiego Towarzystwa Psychologicznego 2009.

28. Swenconis C, Rendell SL. The psychology of obesity. Abdominal Imaging 2012; 37(5): 733-737.

29. Terelak JF, Budka A. Sense of coherence and styles of coping stress in obesity. Journal of Aviation Medicine and Psychology 2014; 20(2): 17-24.

\section{ACKNOWLEDGEMENTS}

The views, opinions, and findings contained in this article are our own and should not be construed as an official Polish Air Force position, policy, or decision, unless so designated by other official documentation.

Cite this article as: Nieśpiałowski A, Trerelak JF. Obesity-Related Self-Esteem and its Relationship to Coping With Stress. Pol J Aviat Med Bioeng Psychol 2016; 22(2): 18-26. DOI: 10.13174/pjambp.31.12.2016.02 